\title{
Malignant Extragonadal Germ Cell Tumor
}

National Cancer Institute

\section{Source}

National Cancer Institute. Malignant Extragonadal Germ Cell Tumor. NCI Thesaurus. Code C8881.

A malignant germ cell tumor that develops as a primary tumor in an anatomic site other than the testis or ovary. 